\title{
Migration and land-use/land-cover change in Burkina Faso: a comparative case study
}

\author{
Elisabeth Kago Ilboudo Nébié ${ }^{1}$ \\ Colin Thor West \\ Columbia University,USA \\ University of North Carolina at Chapel Hill, USA
}

\begin{abstract}
In the Sahelian country of Burkina Faso, West Africa, population pressure, poor resource management, and reduced rainfall have exacerbated land degradation. A rapidly growing population coupled with high rates of internal rural migration and thirty years of desiccation have resulted in profound land-use/land-cover change (LULCC) throughout the country. In the Central Plateau and northern regions of Burkina Faso, land degradation has historically stimulated large-scale out-migration toward more fertile areas in the south. While some northern provinces are being rehabilitated by Soil and Water Conservation (SWC) projects, southern provinces, considered more "pristine", have been neglected. In recent decades, researchers have attributed the initiation of land degradation processes in southern regions to this influx of migrants from the north. This study presents an empirical controlled case study between two provinces to better understand the dynamics of migration and LULC. One province, Bam Province in the north, has long been a zone of departure while Sissili Province in the south has long been a destination zone. Using a regional political ecology framework, we integrate a time series of LULCC data with demographic census data and local narratives to compare migration and LULCC trends in Bam and Sissili from 1975 to 2013. We find that in-migration correlates with substantial and dramatic LULCC while out-migration is associated with only moderate LULCC. This controlled comparison also suggests that local land-use/land-cover change and migration dynamically interact. As environmental conditions in Bam improve and in Sissili deteriorate, long-term trends of either out- or inmigration for either province stabilize, and can even reverse.
\end{abstract}

Key Words: Burkina Faso, LULCC, migration, regional political ecology

\section{Résumé}

Au Burkina Faso, pays sahélien d'Afrique Occidentale, la croissance démographique, la mauvaise gestion des ressources et la réduction des pluies ont accéléré la dégradation des sols. A travers le pays, la croissance rapide de la population ainsi que les forts taux de migrations rurales internes et 30 années de dessiccation ont entrainé de profonds changements dans l'utilisation des terres et des transformations de la couverture terrestre. Historiquement, dans les régions du Plateau Central et du Nord du Burkina Faso, la dégradation des sols a stimulé des migrations à grande échelle vers les zones fertiles du Sud. Alors que certaines provinces du Nord sont en cours de réhabilitation par les projets de conservation des sols et des eaux (SWC), le Sud du pays, considéré « intact », a été négligé. Selon les chercheurs, ces dernières décennies, le flux de migrants venant du Nord serait à l'origine de la dégradation croissante des sols au Sud. Nous présentons une étude de cas empirique et contrôlée entre deux provinces afin de mieux comprendre les dynamiques des migrations et des changements

\footnotetext{
${ }^{1}$ Dr. Elisabeth Kago Ilboudo Nébié, Postdoctoral Research Scientist, International Research Institute for Climate and Society (IRI), Earth Institute of Columbia University, USA and graduate from UNC Chapel Hill (2018). Email: ilboudo_nebie "at" iri.columbia.edu. Dr. Colin Thor West, Associate Professor, Department of Anthropology, UNC Chapel Hill, USA Email ctw "at" email.unc.edu. We would like to thank reviewers and acknowledge funding from the WennerGren Foundation, PEO International, the US National Science Foundation's Research Experience for Graduate Students (REG) program (BCS-1261800), and the Harriett Kupferer travel award from UNC's Department of Anthropology.
} 
d'utilisation des sols et de transformations de la couverture terrestre. Le Bam, l'une de ces deux provinces, située au Nord du pays, a longtemps été une zone de départ tandis que l'autre province, la Sissili, située au Sud, a longtemps été une zone de destination des migrants. Utilisant l'approche d'écologie politique régionale, nous combinons une série de données chronologiques sur les changements d'utilisation des sols et les transformations de la couverture terrestre avec des données démographiques et des récits locaux dans le Bam et la Sissili de 1975 à 2013. Nos résultats montrent une corrélation entre les migrations et les changements dans l'utilisation des sols et les transformations de la couverture terrestre. Les zones d'accueil connaissent des changements importants et dramatiques tandis que les zones de départ enregistrent des changements modérés. L'amélioration des conditions environnementales dans le Bam et la détérioration des conditions dans la Sissili peuvent stabiliser ou même renverser la tendance des dynamiques migratoires.

Mots clés: Burkina Faso, LULCC, migration, écologie politique régionale

\section{Resumen}

En el país saheliano de Burkina Faso, África occidental, la presión demográfica, la gestión deficiente de los recursos y la reducción de las precipitaciones han exacerbado la degradación de la tierra. Una población en rápido crecimiento, junto con altas tasas de migración rural interna y treinta años de desecación, han resultado en un profundo cambio en el uso de la tierra / cobertura de la tierra (LULCC) en todo el país. En la meseta central y las regiones del norte de Burkina Faso, la degradación de la tierra ha estimulado históricamente la emigración a gran escala hacia áreas más fértiles en el sur del país. Mientras que algunas provincias del norte están siendo rehabilitadas por proyectos de Conservación del Suelo y el Agua (SWC), las provincias del sur, consideradas más "prístinas", han sido descuidadas. En las últimas décadas, los investigadores han atribuido el inicio de los procesos de degradación de la tierra en las regiones del sur a esta afluencia de migrantes del norte. Este estudio presenta un estudio empírico entre dos provincias para comprender mejor la dinámica de la migración y LULC. La provincia de Bam en el norte ha sido durante mucho tiempo una zona de partida, mientras que la provincia de Sissili en el sur ha sido durante mucho tiempo una zona de destino. Utilizando un marco regional de ecología política, integramos una serie temporal de datos LULCC con datos de censos demográficos y narrativas locales para comparar las tendencias de migración y LULCC en Bam y Sissili de 1975 a 2013. Encontramos que la inmigración se correlaciona con LULCC sustancial y dramática mientras la migración de salida está asociada con LULCC moderada. Esta comparación controlada también sugiere que el cambio y la migración local de uso de la tierra / cobertura de la tierra interactúan dinámicamente. A medida que mejoran las condiciones ambientales en Bam y se deteriora Sissili, las tendencias a largo plazo de emigración o emigración para cualquier provincia se estabilizan e incluso pueden revertirse.

Palabras clave: Burkina Faso, LULCC, migración, ecología política regional.

\section{Introduction}

Land degradation is the product of long and short-term processes. The Drylands Millennium Ecosystem Assessment (MA) defines land degradation as the "reduction or loss of the biological or economic productivity of drylands" (Adeel et al. 2005: 1). "Land-cover is the observed (bio) physical cover on the earth's surface" (Di Gregorio and Jansen 1998:3). It does not just refer to soil and surface topography, but also incorporates superficial deposits, climate and water resources, and plant and animal communities (FAO and UNEP 1997). Human modifications of a specific land-cover type for productive purposes is "land-use." Land-use is driven by diverse socioeconomic factors (Di Gregorio and Jansen 1998). These factors include local culture, land policies, environmental conditions, the actions of development programs (Ellis 2013), the availability of information and technology in specific socio-economic contexts (FAO and UNEP 1997), and global market prospects and constraints (Lambin et al. 2001). Land-use modifies land-cover, and changes in land-cover transform land-use (Ouédraogo 2010). These dynamic feedbacks are generally referred to as land-use and landcover change (LULCC). LULCC is the conversion of a specific land-cover class into another class due to human interferences (Turner, Moss and Skole 1993). Net LULCC can often appear neutral. However, certain specific changes are negative - i.e., farmland to barren soil while others are positive - i.e., barren soil to farmland. Land degradation is an example of negative LULCC.

In their seminal edited volume Land degradation and society, Piers Blaikie and Harold Brookfield point out that definitions of land degradation are "open to multiple interpretations" based on those of natural 
resources users, managers, and other stakeholders (1987: 4). Their statement suggests that land degradation is ultimately socially constructed and context-specific. There are no universal definitions that apply to all cases. Consequently, we broadly define land degradation through the following equation: "Net degradation = (natural degrading processes + human interference) - (natural reproduction + restorative management)" (Blaikie and Brookfield 1987: 7). Net degradation, which is relative to some specified state or use, is null when the net natural reproduction and restorative action equals that of natural and human degrading processes. In this case, LULCC is minimal. A positive LULCC, which is ideal, implies that rehabilitation efforts stimulate natural reproduction and both processes enhance land productivity. Negative LULCC occurs when human interferences and natural degrading factors exceed natural reproduction and restorative management rates. Here, human and biophysical processes play complementary roles in degrading, minimizing and/or repairing the land. These processes are "dialectical, for, in the course of reshaping nature, society gradually reshapes itself" (Biersack 1999: 9).

In drylands, especially the Sahel of West Africa, net LULCC is often negative or null. When net LULCC is negative, conservation projects aim to minimize or repair it. In these arid and semi-arid regions, the longterm human and natural failure to balance demand and supply for ecosystem services such as water, food, and forage is known as desertification (UNCCD 1994). Thus, desertification (a controversial term) is synonymous with land degradation in these arid and semi-arid areas (Batterbury and Warren 2001). Numerous case studies on land degradation have taken place in Burkina Faso (Batterbury 1997; Gray 1999; Ouédraogo 2010; Marchal 1983). In the central and northern parts of this landlocked country, the fragmentation of agricultural units, decreasing land availability and the expansion of gullies in productive valleys have exacerbated land degradation (Critchley 1991; Marchal 1983). In the 1970s and 1980s, after the severe droughts that affected the northern region of Burkina Faso, the government encouraged the migration of Mossi farmers from these semi-arid, densely populated, and degraded areas to wetter, sparsely populated, and more fertile regions of the southern Central Plateau region of the country (Gray 1999; Ouédraogo et al. 2010).

In response to these droughts and degradation, the northern Central Plateau region has been the site of numerous large-scale Soil and Water Conservation (SWC) development projects (Reij, Tappan and Belemviré 2005). Considered a desertification hotspot, the Bam province in northern Burkina Faso, has been studied intensively by human ecologists (Batterbury 1997; Reij, Tappan and Belemviré 2005; West, Roncoli and Ouattara 2008; West et al. 2014). Scholars conclude that SWC efforts have reversed land degradation and that they have had beneficial impacts on households and communities. In contrast, southern Burkina Faso, once considered 'green' and 'pristine', has been neglected by these initiatives. Globally, LULCC has been generally attributed to population pressure, increasing consumer demand, land-tenure arrangements, access to financial capital, shifts in international trading patterns, and local inheritance laws and customs (Turner, Moss and Skole 1993). More specifically, in Sissili, a province in southern Burkina Faso, LULCC has been attributed to inmigration (Ouédraogo et al. 2010). However, studies that simultaneously compare LULCC and migration dynamics in both 'sources' (regions of origin) and 'sinks' (destination zones) are rare.

We address this gap through a comparative case study of LULCC and migration dynamics in Bam and Sissili Provinces. First, we assess whether these two provinces are either migration sources or sinks. Census data from 1975 through 2006 were used to establish the number of in-migrants, out-migrants and net migration for each province. Next, we evaluate the relationship between migration and LULCC. We hypothesize that LULCC is greater in zones of in-migration and lower in zones of out-migration. While land-cover can be visually observed on-site or through remote sensing, the use of natural and social scientific methods is essential in examining land-use and its changes (Ellis 2013). Consequently, we use environmental (LULC GIS data from 1975, 2000 and 2013), demographic (1975, 1985, 1996 and 2006 lifetime migration records), and fieldwork (summer 2014) data to compare the two provinces.

As a unique and multi-scale approach, regional political ecology can shed light on local and non-local historical, cultural, socioeconomic, and political processes operating at different scales and times. Cumulative LULCC, linked to global ecological changes such as climate change, also have local and regional impacts. Hence, examining the proximate causes of LULCC only at the local level is incomplete because the processes involved in LULCC operate across many spatial and temporal scales (Turner, Moss and Skole 1993). 
We address the issue of scale by drawing on previous social and ecological research on the Sahel of West Africa in general and Burkina Faso in particular to understand local changes in Bam and Sissili.

\section{Literature review}

As a semi-arid country located in Sahelian West Africa, the constraints of its physical environment constitute a major obstacle to the socioeconomic development of Burkina Faso (Figure 1). Emphasizing this natural hardship, popular journalism often portrays Burkina Faso in terms of "low agricultural potential, high risk of destructive topsoil erosion, susceptibility to severe seasonal food shortages, and occasional famine" (Batterbury 1997: 8). Agricultural intensification is "an increase in the effort expended per unit area, to increase total output per unit area and over time" (Batterbury 1997: 6). In the 1970s, highlighting the expansion of barren and denuded land exacerbated by unsustainable extensive agricultural practices and high population densities (50 to 100 people per $\mathrm{km}^{2}$ ), Jean-Yves Marchal stated that in the northern part of the country, there is "no more space" (1983: 54). During this period, the limited availability of cultivable land in this did not lead to a shift to intensive agriculture.

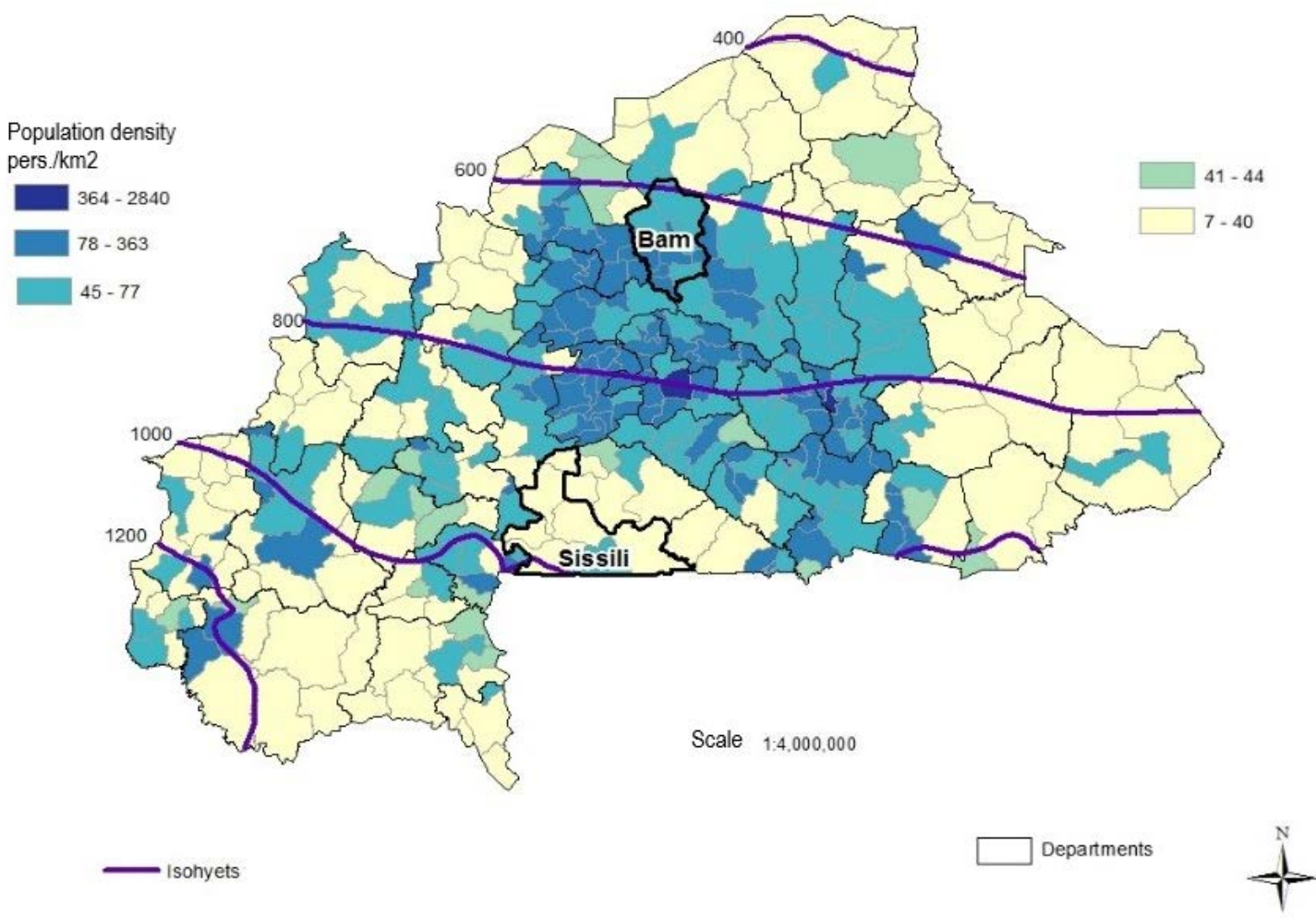

Figure 1: Burkina Faso: population density per $\mathrm{km}^{2}$ and rainfall isohyet zones in 2006. Rainfall generally diminishes to the north: population density is highest in the centre of the country and particularly around the capital, Ouagadougou.

Consequently, Marchal argued that in-situ intensification was not the local response to population growth before the 1970s although, following Ester Boserup's general model of change, it has later become so (Marchal 1987). Mossi farmers eventually transitioned to intensive agriculture - more consistent with Boserup's argument. The Mossi, a major ethnic group and the principal migrants to the southern valleys, have 
nonetheless continued to practice extensive agriculture in the central plateau of the country using traditional methods such as hoe cultivation. Between 1950 and 1980, extensification persisted in the north and animal traction was primarily used to expand cultivated lands rather than to intensify production (Reij, Tappan and Belemviré 2005). The Mossi, as depicted by Marchal, were reluctant to intensify agriculture because instead, they migrated to Côte d'Ivoire and Ghana for work, and some went to the southern river valleys of Burkina Faso (only where free of onchocerciasis, river blindness ${ }^{2}$ ).

\section{Migration to the south}

Migration has been a preferred livelihood strategy for Mossi from the central plateau for almost a century, to overcome food insecurity in the northern region. Before their independence coastal countries such as Ghana and Côte d'Ivoire experienced intensive economic development led by their colonial powers. The development of coastal plantations to the south created a call for free and cheap labor from the early 1900s (Meissalloux 1975), siphoning cheap labor, able-bodied young men from drylands such as Burkina Faso (then called Upper Volta), considered as 'non-viable peripheries' but rich in manpower (Songré et al. 1974). Colonial administrators, therefore, treated the densely-populated regions of Burkina Faso as labor reserves to support coastal development and they invested little in the French West African interior.

The Mossi, historically known as 'land conquerors' (Marchal 1983), were more inclined to respond to the call for labor in coastal countries because of declining agricultural productivity, limited off-farm opportunities, high population densities and increased food insecurity in their homeland. The residents of Bam are mostly Mossi, still farming and practicing labor migration. In addition in 1914, Mossi migration to Britishcontrolled Ghana was not only a 'voluntary' strategy to escape military recruitment for World War I and forced labor under France, but also a way to gain income to pay head taxes due to the French administration (Cordell et al. 1996). In contrast, Mossi forced migration towards Côte d'Ivoire was stimulated by the need for labor in cocoa plantations and public works such as the transportation systems being built to link French West African colonies (Songré et al. 1974). In 1946, forced labor was abolished, making migration a 'voluntary' choice. However, "... migrants vote with their feet, the choice of paths is determined by forces in the larger system beyond their control, and may not be in the interests of their household and communities, or, therefore, in their own long-term interests" (Cleveland 1991: 240). Therefore migration became the most viable alternative for Mossi smallholders in times of environmental hardship. Even today, there are few viable options to earn cash and sustain a living in their homeland (although some gold mining has emerged since the 1980s).

By the 1980s, Mossi migrations had reshaped the economy, demographics, and land-use patterns of the center-north and southern provinces. The center-north regions "differed from the rest of the country with relatively low rates of economic activity, lower percentages of males in the population, a low representation of people aged 15-64, and a high percentage of cultivated area" (Henry et al. 2003: 119). Marchal states:

Peasants prefer buying bicycles than plows. They escape [...] to come back with motorbikes and leave again after selling them. These people, who claim that they do not have money to invest in agricultural means of production (that would promote their living standards) have chosen to either settle somewhere else, or stay at home but by relying on external income. The system works. It is not blocked; it has dilated to cover a wider space. (1983: 814, translation from French)

In order to overcome the environmental, economic and social challenges of the northern regions of the country, the government of Burkina Faso actually promoted internal migration from more degraded and highly populated northern provinces to less degraded and less populated southern river valleys (McMillan 1983). In the 1970s, Burkina Faso (then Upper Volta), as the legal proprietor of any 'unoccupied', 'underpopulated' or

\footnotetext{
2 The World Health Organization (2015) defines onchocerciasis as a parasitic disease caused by the repeated bites of Onchocerca volvulus, a filarial worm. This worm breeds in remote villages with fertile agricultural land usually along rivers and streams.
} 
'unimproved' land, launched the programs d'Aménagement des Bassins de la Volta (Volta Valley Authority or AVV). These programs aimed to voluntarily relocate people from drought affected areas toward southern river valleys that had been cleared of onchocerciasis, which were more productive but still underpopulated (McMillan et al. 1993). It was onchocerciasis that had kept population density low in the river valleys for centuries (McMillan 1995) though in Sissili (which counted less than 20 inhabitants per $\mathrm{km}^{2}$ in river valleys), it was also true that rivers served as natural barriers against outsiders, repelling some settlers (Duperray 1984).

The AVV project contributed substantially to local, regional, and national development goals (McMillan 1983). This resettlement program not only addressed the Central Plateau's pressing economic, environmental, and demographic issues, but also the declining position of Burkina Faso's cotton production and international trade. To overcome this decline in production, the AVV promoted intensive agriculture and resettlement areas as a way to boost cash crops and move beyond subsistence agriculture. In Settlement and development in the river blindness control zone: case study of Burkina Faso, McMillan et al. (1993) mapped the AVV planned settlement locations between 1973 and 1984. Her map shows that although Sissili - home to the Gurunsi ethnic group - has not officially hosted an AVV settlement, the province was surrounded by settlements in Nahouri (another Gurunsi homeland) and Zoundwéogo. In addition, Sissili is not an area of active gold mining, but industrial and artisanal gold mining are key activities in the surrounding provinces of Nahouri, Zoundwéogo, Boulgou, Balé and Bougouriba (Jaques et al. 2006). Since the 1990s, many artisanal gold miners have progressively left gold-producing areas in the northern zones of the country to migrate south toward new grounds (Jaques et al. 2006). Short-term migrants to mine sites have altered the demographics of certain provinces and contributed to land degradation. The proximity of Sissili to these settlements could explain intensive migration in the province during the AVV programs and perhaps spontaneous un-assisted migration during the gold rush. The major ethnic groups migrating to Sissili are Mossi smallholders and Fulße pastoralists (traditional herders involved in seasonal livestock movements).

In the southern river valleys, which used to be sparsely populated because of disease risk as we have shown, rapid population growth and the conversion of forest and savanna into cropland and grazing land followed these migrations (Ouédraogo et al. 2010; Paré et al. 2008). Substantial changes in these valleys confirm Henry et al.'s argument that "migration driven by rapidly changing environmental factors are likely to be more massive and rapid than migrations driven by slower socio-demographic changes" (2003: 117). In the 1985 census, population density in certain southwestern areas has doubled compared to previous censuses, creating issues related to land access and use: the highest rates of in-migrants were recorded in provinces such as Sissili (4.88\%) and Kadiogo (3.36\%) (Henry et al. 2003: 120).

\section{Developments in northern provinces}

While this migration was taking place toward the south, population densities were still higher in the northern and central provinces (Figure 1). Poor living conditions and land degradation in the north spurred the attention of international organizations and the implementation of dryland Soil and Water Conservation (SWC) projects. In certain northern provinces such as Bam, mining, coupled with SWC projects, enable local residents to diversify their livelihoods (West 2010). Examples of SWC techniques include contour stone bunds (locally referred to as diguettes), semi-permeable dikes, and zaï pockets (West et al. 2014). These projects aimed to improve rural livelihoods by "[rehabilitating] the productive capacity of the land through better control of rainfall and runoff, as well as through improved soil fertility management and reforestation" (Reij, Tappan and Belemviré 2005: 643). These projects emerged during the colonization era and continued after Independence in the 1960s. At the height of interest in SWC in the 1990s, Critchley still noted that:

Concern about soil conservation is nothing new in Africa [...] In the British-ruled territories soil conservation became a major issue during the 1930s [...] But the majority of these schemes were resented by the local people, who were forced to supply labour [...] Soil conservation was seen as being a form of colonial oppression. It is not surprising then that independent Governments found it difficult at first to support soil conservation programmes. When conservation projects 
did begin to reappear, many of the same old mistakes were made again. Until very recently there has been a long list of soil conservation failures. (Critchley 1991: 4)

Initial SWC projects failed when local communities and their land use practices were considered as the problem rather than the solution. Learning from the failure of such projects, PATECORE (Projet d'Aménagement des Terroirs et Conservation des Ressources dans le Plateau Central) successfully built on diverse local knowledge to create more sustainable land use management techniques in Bam Province from the late 1980s. These projects became successful and sustainable when they combined modern conservation techniques with traditional practices. While farmers were encouraged to improve traditional planting pits or zaï, non-governmental organizations' technicians focused on contour stone bunds (Batterbury 1997; Kaboré and Reij 2003). Zaï, one of the most successful techniques, are improved traditional pits created on farms at the beginning of the rainy season to store water and organic matter for improved soil fertility (IFAD 2011). Since the mid-1980s, investments in SWC have improved yields and activated agricultural intensification (Reij, Tappan and Belemviré 2005). Combined, these SWC measures have improved rural livelihoods.

While soils and vegetation in the north were being restored by SWC, similar initiatives were nonexistent in the south. As a legacy of the AVV and structural adjustment programs (SAPs), agricultural entrepreneurship boomed in Sissili starting in the late 1990s. Initially, this came in the form of commercial cotton production, which eventually led to fruit tree plantations as well and, most recently, ranching. Thus, local land-use practices gradually became geared to global export markets. In most rural areas of Burkina Faso, migrants obtain land as a 'loan' in which they have use-rights to individual fields but do not retain actual ownership. Cotton is an annual crop and poses few land tenure problems; farmers supply a portion of their cotton harvest as 'rent' for borrowing land. Fruit trees, on the other hand, are perennial and permanent. They require special permission and can be seen as staking a claim to borrowed land. Thus, the extent of investments in tree-planting varies either by the wealth of farmers (Gray 2005) or by the nature of local land tenure regulations (Paré et al. 2008). On the one hand, Gray (2005) explains that wealthier farmers, who can afford chemical fertilizers, are less concerned about the density of trees in their fields than poorer farmers. On the other, poorer households value higher tree densities on their own land as an inexpensive and sustainable form of soil amendment because additional leaf litter adds organic matter. This soil organic carbon slowly changes the soil structure but trees reduce the amount of area that can be cultivated. Likewise, fruit trees make it more difficult to use animal traction to prepare and weed. Interestingly, Gray (2005) points out that soil nutrient analyses indicate that fields with higher levels of animal traction and fertilizer have lower fertility levels than fields without. Nonetheless, while poorer farmers' practices mitigate environmental degradation, their lower participation in intensification has negative subsistence and economic development costs.

Sadly, many development and conservation projects have failed to consider these parameters as well as external factors that influence LULCC. In Sissili, local land tenure prevents migrants from planting trees because planting trees is a sign of land appropriation (Paré et al. 2008). These restrictions negatively influence LULC in the long run. To date, most research on population and the environment in the Sahel, and particularly Burkina Faso, have studied migration and land-use/land-cover change through isolated case studies in either sending or receiving regions.

\section{Data and methods}

In this article, we offer a controlled comparison of two distinct regions of out-migration (Bam) and inmigration (Sissili) within the same country. We synthesize a time series of secondary census and spatial landuse/land cover data to compare trends in migration and LULC change for the two provinces. We also incorporate ethnographic fieldwork in both Bam and Sissili to explain the trends and patterns we detect. 


\section{Census data}

We extracted lifetime migration data for Bam and Sissili from the published tables in four national censuses conducted by the National Institute of Statistics and Demography (INSD). INSD's lifetime migration data from the 1975, 1985, 1996 and 2006 censuses were used to compare net in-migration and out-migration for both provinces. Due to recent political instability, no national census took place in 2016. INSD defines a person as a migrant when this person's place of residence (household location or 'concession') differs from his or her place of birth. A lifetime migrant is an individual who has relocated to an administrative unit other than their place of birth at the time they were surveyed (Dabiré, Koné and Lougué 2009; Tarver 1992). Lifetime migration data was used because short-term migration reflects seasonal rather than permanent migration, being temporary and have little long-term impact on LULCC. Net migration is the difference between in-migration and out-migration (net migration = number of in-migrants - number of out-migrants) of a given population for a given period of time (OECD 2005). Net migration is negative when the number of out-migrants exceeds the number of in-migrants (OECD 2005) and positive when the number of in-migrants exceeds the number of outmigrants. Certain INSD reports present migration rates based on the hierarchy of administrative divisions by region (the largest), province, and department/commune/prefecture (the smallest). Other INSD reports provide information within only one specific administrative boundary. We used province-level data for the 1985, 1996, and 2006 censuses. Administrative boundaries, however, changed over time. In the case of the 1985 census, we used the departments of Kongoussi (based around the town of the same name) to represent Bam Province and Leo to represent Sissili Province.

In the INSD censuses, residency status is defined at all geographical scales while birthplace is defined by prefecture. In the 1975 census, people were asked to list their birthplace by prefecture, but data were analyzed based on departments. A prefecture in Burkina Faso is considered one of the most stable and enduring administrative units in the country. In the 2006 census, the major change has been the use of commune, instead of prefecture, as the smallest unit in identifying birthplace (Dabiré, Koné and Lougué 2009: 28). However, considering the high number of prefectures and communes (more than 300 communes in 2006), data was analyzed by INSD based on the larger departments in 1975 (there were 10 departments in 1975), and provinces in 1985, 1996 and 2006 (there were 30 provinces in 1984 and 45 provinces in 1997).

One of the challenges in gathering information on migrants' place of origin and residency is that respondents (concerned individuals and third persons) might know the name of their village of birth or residency, without knowing the name of the former or newer higher administrative unit linked to that specific village (Dabiré, Koné and Lougué 2009). These issues are exacerbated by high illiteracy rates in rural areas. Thus, the trends we detected in net-migration for Bam and Sissili are problematic and we simply acknowledge the limitations of the INSD data with which we worked.

\section{Geographic Information Systems (GIS) data}

Remote sensing specialists of West Africa collected and analyzed the Burkina Faso Land-Use and LandCover Maps and Trends dataset (BF-WALULCT) as part of a comprehensive satellite data archive of West Africa Land-Use and Land-Cover Trends for AGRHYMET (Tappan 2013). This BF-WALULCT raster data was processed into ESRI's ArcGIS 10.2, projected to Abidjan 1987 UTM Zone 30N and clipped to the boundaries of Bam and Sissili. We tabulated and summarized area statistics of each land-cover class for each province in 1975, 2000 and 2013 using the ArcGIS Spatial Analyst extension and the Zonal Statistics tool. We then created LULCC charts based on the following LULC classes: gallery forest, savanna, wetland, steppe, agriculture, water bodies, rocky land, bare soil and settlements using Excel.

\section{Fieldwork}

Fieldwork offers a powerful complementary lens for understanding local human-environment complex interactions behind the pixels (Jiang 2003). Ground truthing, more specifically through a modified Participatory Rapid Rural Appraisal (PRRA) method, provides insights from local people about local processes (Chambers 1994). This approach provides important contextual information on ecological conditions and humanenvironment interactions in a timely manner. In order to ground-truth the LULCC data for Bam and Sissili, we 
travelled to Burkina Faso from July to August 2014. Fieldwork entailed meeting with experts in environment, food security, and demography from the Famine Early Warning Systems Network (FEWS NET), INSD, the West African Science Service Center on Climate Change and Adapted Land-Use (WASCAL), National Population Sciences Institute (ISSP), Access to Energy Services Project (PASE), and the National Bureau of Soils (BUNASOLS) in Ouagadougou. In Kongoussi, the provincial capital of Bam, four interviews were conducted with a farmer, a town elder (who provided an historical view of LULCC) and two experts in SWC. In Léo, two farmers, a water and forest agent at the provincial ministry of the environment, a government official, a land tenure specialist, and a coordinator at the provincial Ministry of Agriculture were interviewed. Altogether, the number of interviews is small $(n=20)$ but the first author was born and raised in Burkina Faso. She spent summers living with relatives in Sissili. The co-author has conducted intensive anthropological fieldwork in northern Burkina Faso since 2002. Thus, the participatory fieldwork described here is

supplemented by years of local interactions with rural smallholders in Bam and Sissili.

In these interviews, the team solicited responses to Google Earth satellite images from November 2006. This corresponds to the dry season when fields, trees, diguettes, and other prominent features of the local landscape are readily apparent. These color images of the area around Kongoussi and Léo were printed on 8.5x 11 inch photographic paper using a standard ink-jet printer to a scale of approximately 1:5,000. These correspond to an area of roughly $1 \mathrm{~km}$ by $1 \mathrm{~km}$ for each location. During the interviews with the farmers, we experimented with an interactive participatory approach using these images. At the beginning of the exercise, participants were trained to recognize major roads, buildings, and other features to orient themselves. Then, they were asked to locate specific agricultural, barren and rehabilitated lands. Last, the farmers were asked to describe LULCC trends on these specific lands over their lifetime based on their own personal experiences. Information about changes in rainfall, land tenure, land-use practices, and migration were also collected. Interviews were conducted in Mooré and in French and notes were handwritten. The first author, who is fluent in Mooré and French, then transcribed these fieldnotes.

\section{Results}

\section{Demographic data}

Published tables from the four censuses were used to characterize migration trends for Bam and Sissili in 1975, 1985, 1996, and 2006. Figure 2 below shows the number of lifetime in-migration, out-migration, and net-migration for the two provinces. The data shows that Bam has always been a net migration source since 1975, but that both types of migration had diminished dramatically by 2006. Likewise, the data shows that Sissili has been a significant migration sink since the same time, but that in-migration had also diminished by 2006. Thus, between 1975 and 1996, Bam was primarily a province of origin for internal migrants and Sissili a destination. By 2006, however, these trends had largely ceased and migration had stabilized for both provinces. In fact, long-term patterns of out-migration from Bam had reversed by 2006; it became a net 'sink' of in-migration - although this is very slight.

\section{Geographic Information Systems (GIS) maps and graphs}

Land degradation has been a significant driver behind migration out of Bam until the 1990s (see Reij, Tappan and Belemviré 2005). In Sissili, however, in-migration has often been listed as one of the major causes of negative net LULCC (Ouédraogo et al. 2010). Since land-cover conversion from one class to another is the product of long-term processes, we compare LULCC data over a 38 year period. While LULC collected in 1975 and 2000 roughly correspond to periods in the census on migration, there has not been a census since 2006 to cross-check with the 2013 LULCC data. Yet, the 2013 LULCC data describes the most recent state of LULCC in the study areas. Overall, Figures 3, 4, 5, and 6 illustrate that from 1975 to 2013, Bam and Sissili have undergone profound changes. In particular, agricultural land has increased in both provinces. The expansion of agricultural land in Bam, however, is modest compared to Sissili. 


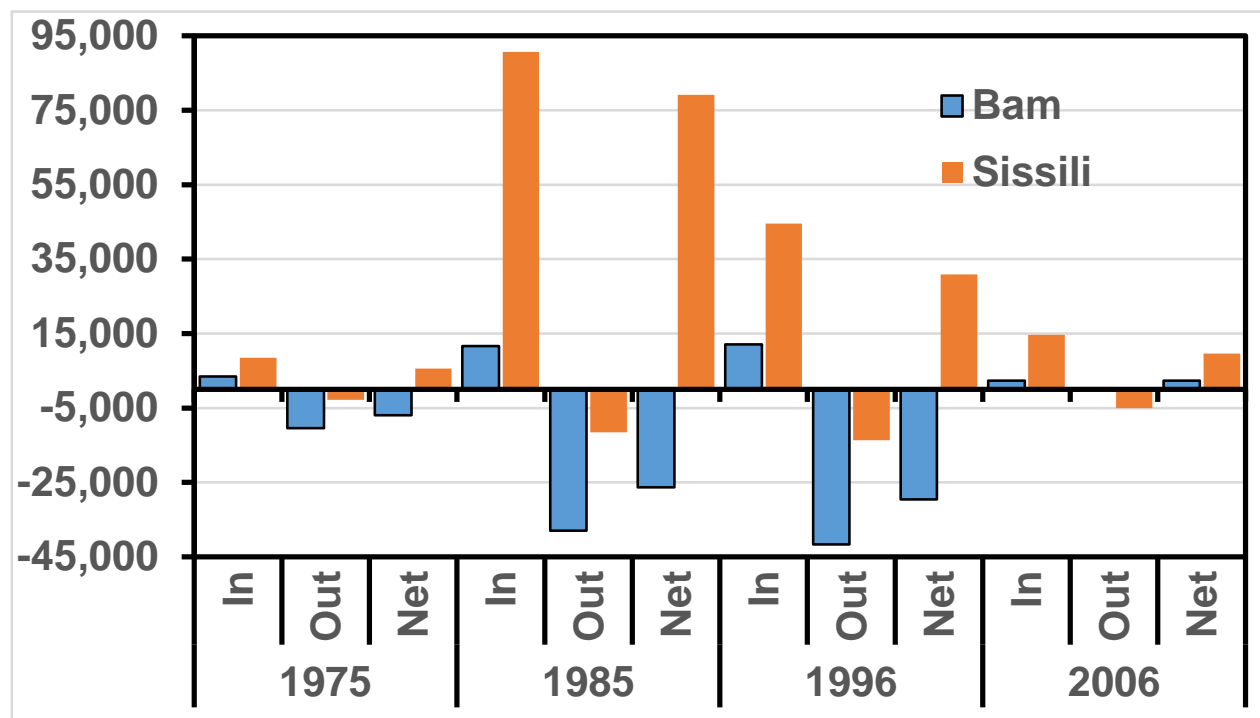

Figure 2: Net migration trends for Bam and Sissili Provinces: 1975, 1985, 1996, and 2006. Source: Dabiré, Koné and Lougué 2009; Drabo, Ilboudo and Tallet 2003; INSD 1985, 1975a and $1975 b$.
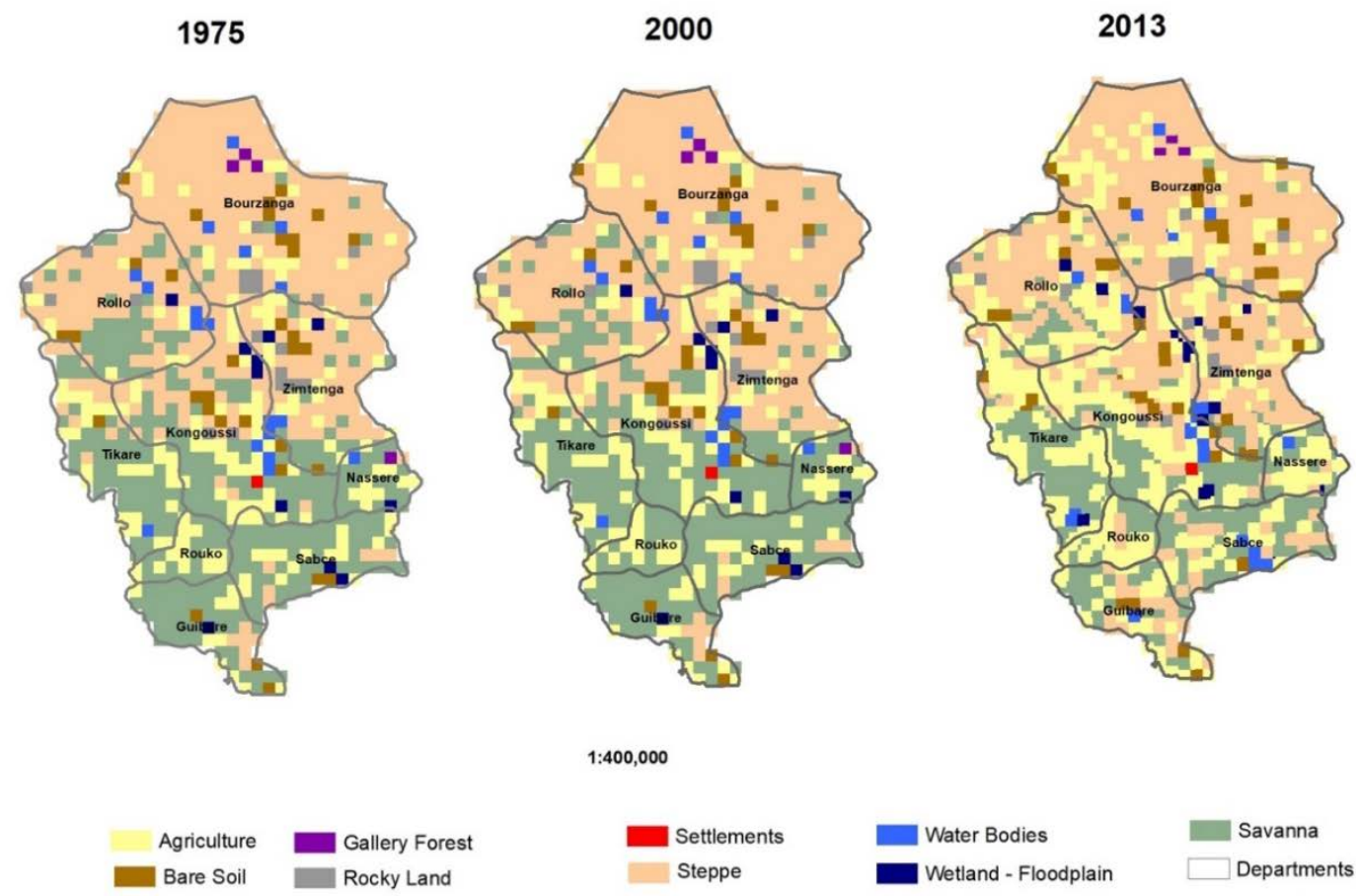

$$
1: 400,000
$$
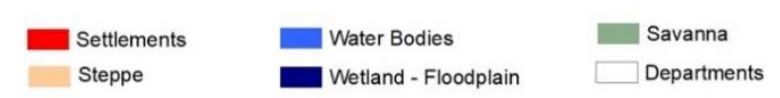

Figure 3: Bam Land-Use/Land-Cover Change -- 1975, 2000 and 2013. 
Bam

Figure 3 above describes LULC change for Bam at three distinct time periods. The maps show that agriculture has increased, but that it has expanded mostly in the central and southern areas of the province. Moreover, the most significant change occurred between 2000 and 2013. Figure 4 indicates that agriculture increased by 5.7 percent between 2010 and 2013 and suggests that it replaced savanna areas. Nonetheless, steppe and savanna remain the dominant land-cover classes in Bam and together comprise approximately between 74 and 64 percent of the total area during this period.

\section{Sissili}

Figure 5 shows LULC change in Sissili for the same three time periods. Compared to Bam, land-use/landcover change has been much more dramatic. Agriculture has expanded throughout the entire province and become the dominant land-use type comprising 53.1 percent of the total area in 2013 (Fig. 6). Like Bam, agriculture expanded most rapidly between 2000 and 2013, but this increase was much more significant - 27.9 percent. This has been at the expense of savanna, which decreased from 85.2 to 42.3 percent from 1975 to 2013.

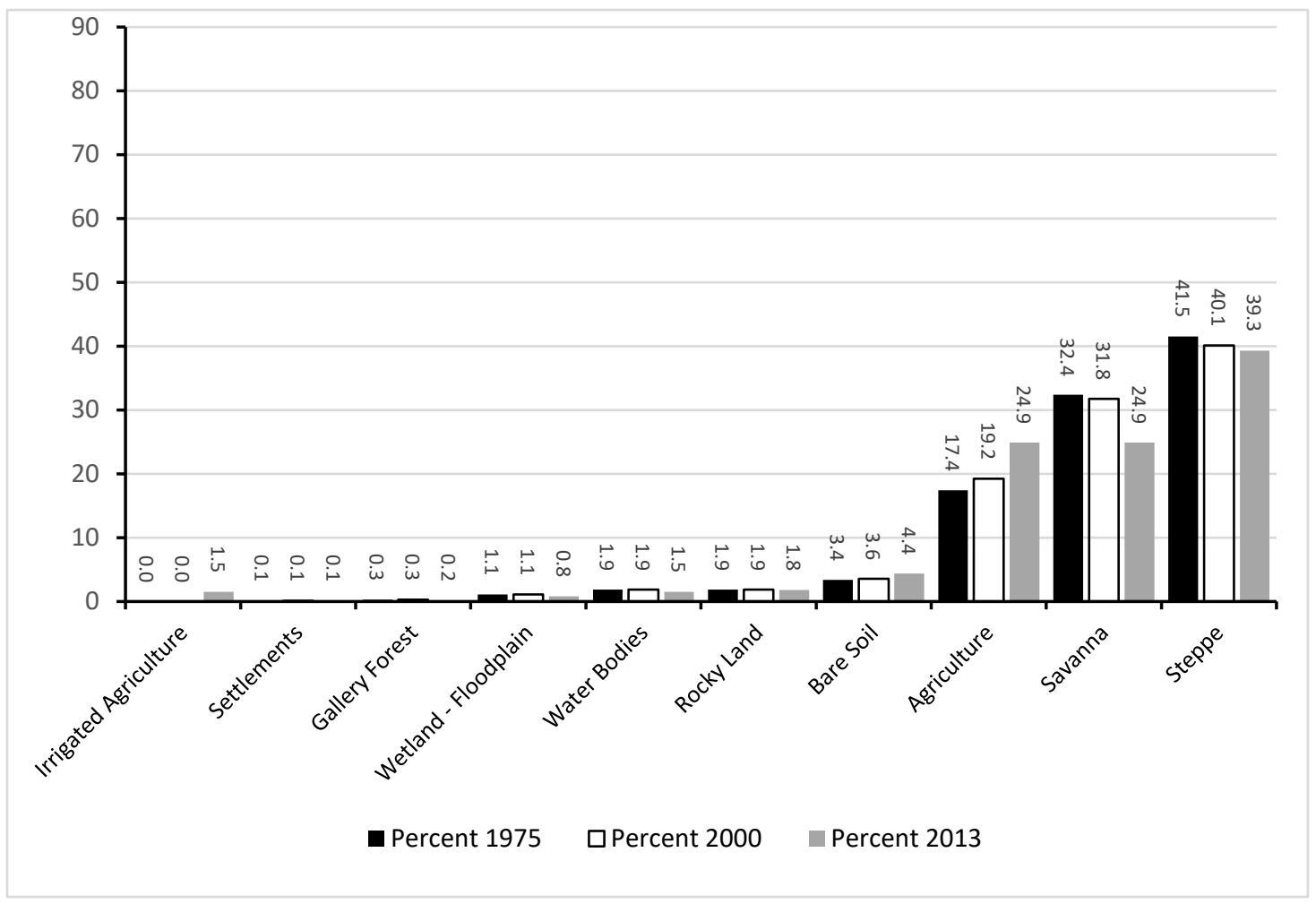

Figure 4: Bam province: percentage change in Land-Use/Land-Cover classes - 1975, 2000, and 2013. 

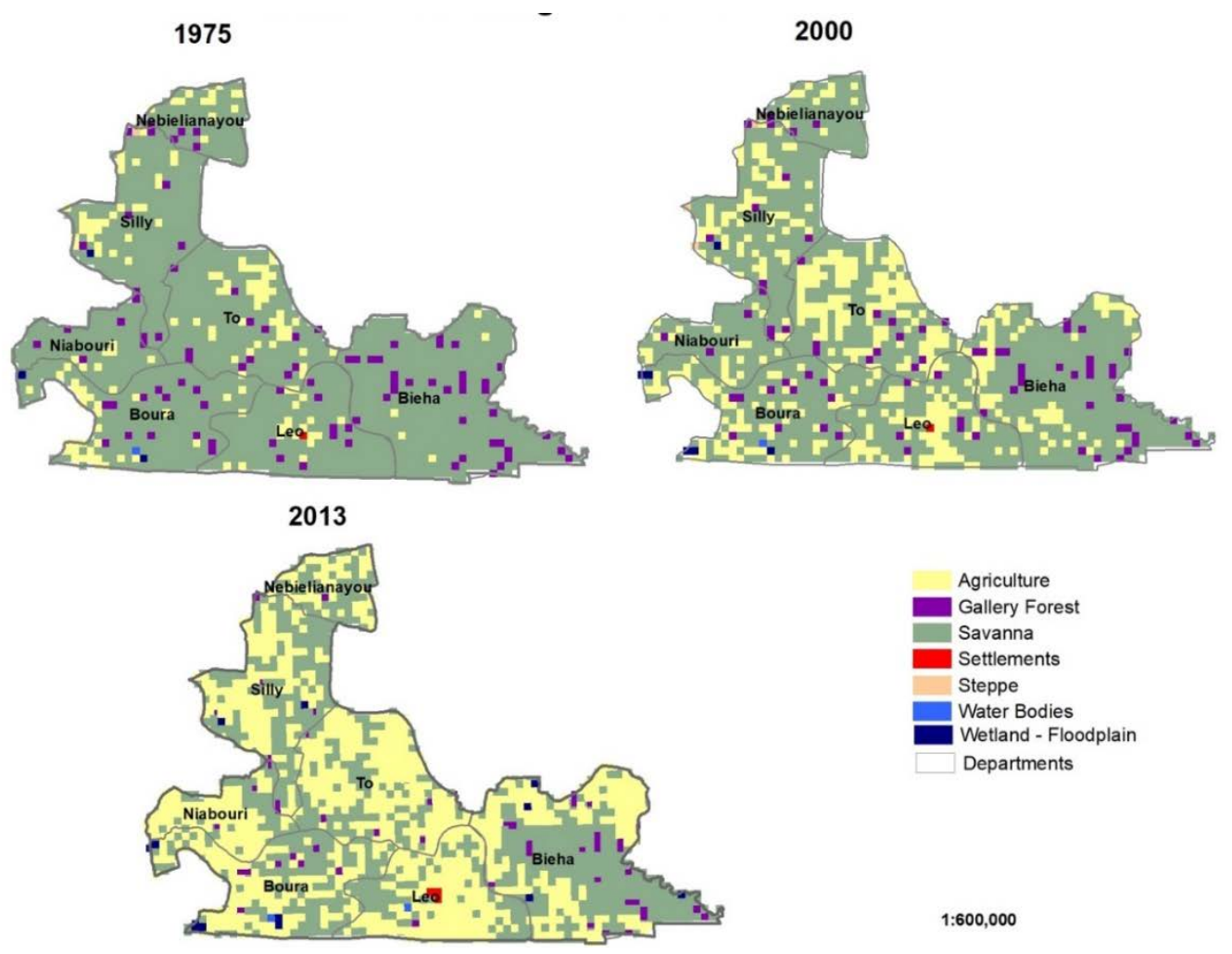

$1: 600,000$

Figure 5: Sissili Land-Use/Land-Cover Change - 1975, 2000 and 2013.

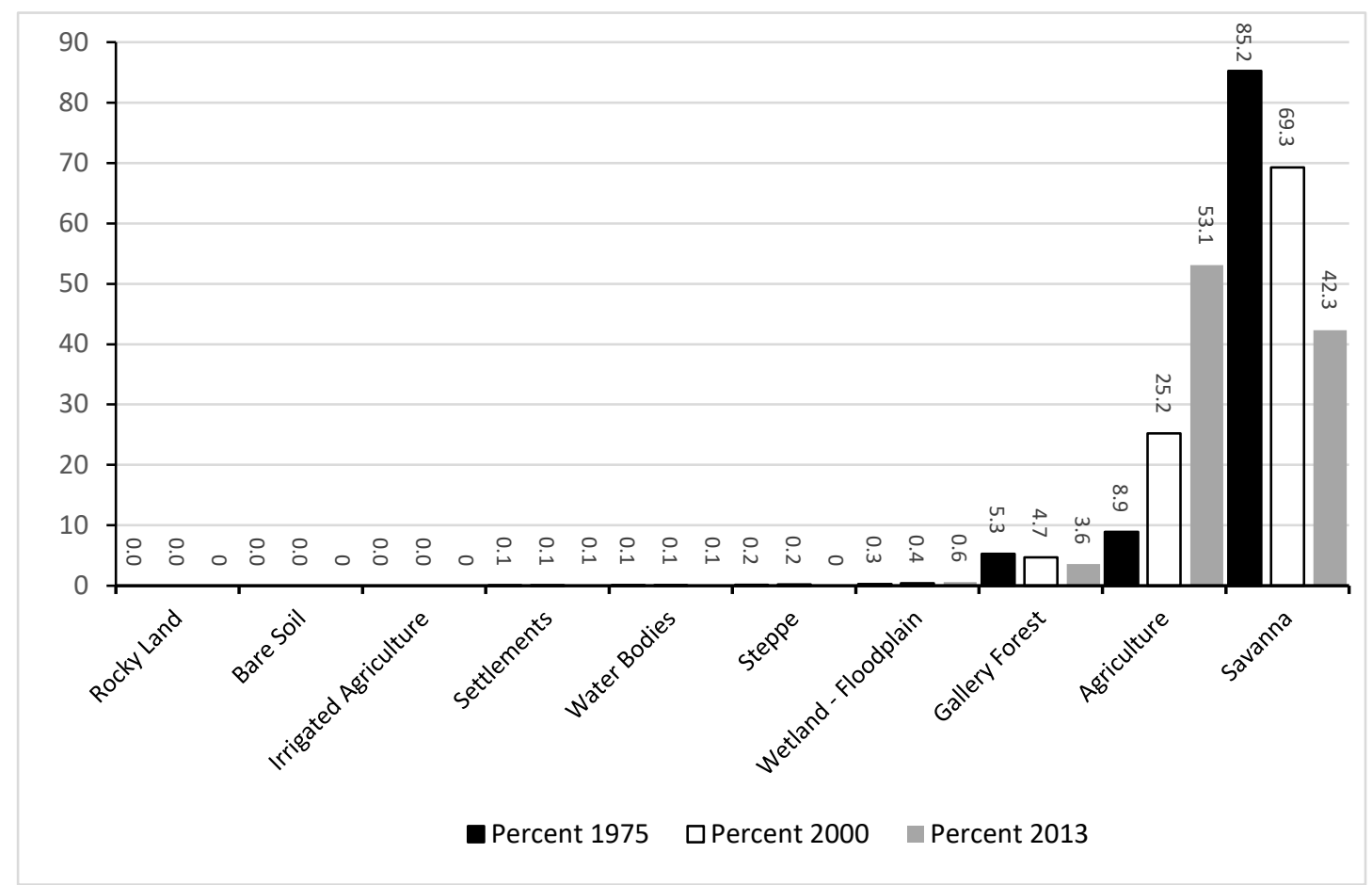

Figure 6: Sissili percentage change in Land-use/Land-Cover classes - 1975, 2000, and 2013. 


\section{Local narratives}

Local narratives provide place-based explanations for these LULC trends. The intention of this research is "not to replace one version of truth with another, but rather to add the version that people, whose livelihoods are directly affected by these changes, themselves contribute to the scholarly debate" (West and Vásquez-León 2008: 381).

Local rural producers explained LULC trends in terms of land tenure systems, migration, population pressure, rainfall, and specific agricultural and forest land-use practices. However, the experts interviewed argued that the underlying and proximate causes of LULCC differed from one area to another and that their patterns and extents also vary. While experts described northern Burkina Faso as "browner" migration sources with lower land availability, southern provinces were considered as 'greener', but degrading migration sinks.

Bam

In Bam, and more precisely Loulouka and Kongoussi, our participants attributed moderate LULCC to SWC projects, rainfall recovery, land tenure systems and reforestation. Experts described population pressure and deforestation as the major causes of the severe famines in the Sahel in the 1970s and 1980s. In this process, one farmer (PZ) argued that "space to plant trees is hard to find when we need fields to grow subsistence crops." Remembering this period, LS, a town elder in Kongoussi provided an historical perspective on how rainfall relates to tree cover, agricultural production, food insecurity, and migration in Bam. He stated: "This is unforgettable. It didn't rain and experts said there weren't enough trees... We went two to five days without eating. The lack of rain was the main cause of this hunger." According to LS, overcoming hunger has been a "household-to-household matter." In times of famine, while the poorest families depended on food aid, he says, some bought food on the market or others chose to migrate. Thus, the impacts of droughts varied by households within a community.

Migration and food exchanges have connected rural livelihoods between Bam and Sissili. LS continued: "When there is a lot of grain here in Kongoussi and no grain in Léo, we can also send them grain ....In the past you had to send food through transportation or delegate someone to bring it. Nowadays...you can send money with...Western Union." Sharing a personal story, he explains how Bam migrants remain attached to traditional customs in their homeland while residing in Sissili: "They just went to Léo to ask for land and cultivate ... but they come back to their Bayiri [homeland] for wedding and funeral rituals." This attachment to their natal village demonstrates the need to study migrants' destination areas in context with their region of origin.

PZ, a farmer in Loulouka, argued that in Bam, "demography has changed and is different from the past." Moderate population growth had stimulated a moderate expansion of agricultural land (7.5\% from 1975 to 2013 - Figure 4), creating new types of complex negotiations and land tenure arrangements among ethnic groups, especially between farmers and pastoralists. PZ, who accessed several spatially dispersed agricultural fields, indicated fields on the map that he borrowed from a pastoralist. The remote location of this field from Loulouka and the fact that it had never been cultivated in the past suggests that agricultural land is increasing and encroaching on steppe), but incrementally (see decreased steppe in Figure 4).

Out-migration, according to LS, was much stronger during the major droughts, but population had been increasing in Bam due to the SWC projects. Today, thanks to SWC techniques, agricultural expansion is now possible on bare soil. Indeed:

Zipélé [bare soil] is now rehabilitated and put into production. There is no more zipélé here because of demographic pressure and there is also no more space to cultivate because there are too many people. Nowadays, zaï is still practiced, but now on zipélé which has been rehabilitated and produces better than non-zipélé and bas-fonds [low-lying areas]. Even if you can't do zaï every year, you can use the ones from the previous year because the crop residues can replace organic matter and reinforce your zaï. PZ, a farmer in Loulouka 
None of the participants specifically mentioned the role of the gold rush and its demographic effects in Bam. However, our observations have shown that mining is also increasing migration into the area. The opening of a very large commercial mine to the south near Sabçé, fairly close to Kongoussi town, has led to an influx of migrants from other parts of Burkina Faso. In fact, Dioula - a language of south-west Burkina, is now commonly heard in the provincial capital Kongoussi whereas only Mooré and Fulfuldé were previously dominant.

Sissili

In Sissili, especially in the communities of Léo and Biéha, participants recognized decreased rainfall, population pressure, deforestation and the commodification of agricultural land as the primary causes of LULC change. Aware of environmental changes in the province, farmers argued that "in the past, it used to rain from May to October. But nowadays ... we have only four months or sometimes four months-and-a-half of rain." $\mathrm{KM}$, a farmer and trainer in Léo. AN, a farmer and town official in Léo described these rains as heavy and destroying about $10 \%$ of trees. In addition, in the 1990s, in certain villages of Sissili such as Yalé, "migrants constituted about one-tenth of the autochthonous population. Nowadays, the number of migrants in Yalé is three times the number of autochthonous inhabitants." - KM, a farmer and trainer in Léo. Sadly, AN added, "Here, people do not work on restoring soils [i.e., through SWC] and they do not like using it [i.e., SWC] as elsewhere in Burkina. Instead, they prefer using fertilizer...There are no reforestation programs in Léo apart from the few trees that people plant on their farm land. This is a weakness." In Sissili, instead of initiating SWC projects to overcome the new environmental challenges, farmers had been trained to plant improved short cycle crops, especially genetically-modified (GM) maize such as Barka, SR21, FBC 6, Kamboinsé Précoce Jaune (KPJ), and Kamboinsé Précoce Blanc (KPB).

In Sissili, the fragmentation of production units from extended to nuclear households and the introduction of animal traction and ploughs have increased the amount of cultivated land. KM, a farmer and trainer in Léo, described: "In the past, 5 hectares of agricultural land was enough to feed 10 people in a family but, nowadays, with the use of herbicides and animals (draft animals), every person wants their own 5 ha to exploit themselves." In these individualistic production units, decisions that were once made by the elder or chief of a group are now made individually by each migrant. To explain local perceptions of land-use patterns by ethnic group, an expert from ISSP shared that one of his professors used to claim that "Après les Mossi, c'est le desert!" ["After the Mossi, comes the desert!"]. Leaving one place to conquer another one, is indeed the pattern of Mossi chiefdoms since the $15^{\text {th }}$ century. In previous migration waves, the Mossi have abandoned the 'old' Yatenga ${ }^{3}$ to go and create new Yatengas elsewhere (Marchal 1983). Thus, these Mossi migrants practice traditional extensive agriculture used in their home regions to rapidly expand cultivation in new areas.

Growing land scarcity and the fear of losing loaned land to migrants have pushed autochthonous peoples to prohibit long-term investment on the land such as on-farm tree planting. One participant explained: "Mango trees take a long time to grow. If I gave you a land to cultivate and I find out that you are planting many mango trees on it, I will start thinking that you want to keep the land. So, I will make sure that you give me back my land." - ZI, a local historian in Léo. This unsecure land tenure system is a threat for reforestation initiatives undertaken by migrants. Although destination areas were underpopulated, "they were never unclaimed" (McMillan et al. 1993: 38).

Lately, in Sissili, the lack of respect for traditional land tenure norms and livestock wandering in agricultural fields have been stimulating conflicts between migrant Mossi farmers, Fulße pastoralists and autochthonous Gurunsi. Looking at the increasing migrant-autochthonous conflicts in the Sissili ZI, a local historian in Léo warned: "we are afraid that this zone will become a poudrière (battlefield) because there are sales and double-sales of the same plots of land." This is contrary to departure areas such as Bam where land is not sold, but rather used exclusively for subsistence crops, which does not lead to land-grabbing (Stamm et al. 2003). In addition, the creation of the pastoral zone of Yalé after the droughts of the 1970-1980s has

\footnotetext{
${ }^{3}$ Province of northern Burkina Faso similar to Bam in terms of landscape and population. Marchal (1983), who studied the Mossi of Yatenga, argues that there was no more space to extensify agriculture, leading to migration. This was prior to the arrival of large SWC projects.
} 
increased the migration of Fulße pastoralists into the province. This has increased livestock density and the proportion of grazing lands in the region. Uncontrolled grazing has since then increased crop insecurity and farmer-herder conflicts (Paré et al. 2008).

\section{Discussion}

\section{Sissili has been a migration sink: LULCC is dramatic}

As a fertile valley, Sissili has been a migration sink since the development of the AVV programs in the 1970s. McMillan et al. (1993) predicted the increasing settlement and demographic growth in the southern valleys during the crisis of the cocoa market in Côte d'Ivoire and the subsequent return of Burkinabè migrants to their home country. They argued that it would be "naïve to think that many of these immigrants, especially those who remained for long periods of time in Côte d'Ivoire, would go back to the impoverished Mossi Plateau" (McMillan et al. 1993: 11). Between 1975 and 1996, Sissili has been one of the preferred destinations for migrants. This period of in-migration, characterized by the expansion of fragmented agricultural fields, decreased savanna land and incipient land degradation, correlates with increased population density and high LULC change - notably the expansion of agriculture.

Between 1996 and 2006, Sissili received the lowest number of in-migrants since the implementation of the AVV programs. This period corresponds to lower LULCC. The lack of SWC projects to rehabilitate soils in Sissili, and the developing opportunities created by these projects in addition to gold mining in northern Burkina Faso can explain these trends. Decreasing net migration implies that as population has grown in Sissili, farmland has become scarce and less productive. In fact, the analysis of land-use/land-cover data strongly suggests that Sissili is now saturated and agriculture can no longer expand (Figure 5). In addition, local narratives suggest that decreased migration can also be explained by deteriorating relationships between migrants and autochthonous communities due to reduced land availability and land tenure challenges. This scenario suggests that the current reasons to migrate to Sissili are mainly motivated by non-farm income generating opportunities including commerce and business. Farmers' decisions to migrate are largely determined by the lack of economic opportunities in their region of origin. The SWC programs and the new job opportunities in gold mines have alleviated economic disparities between the southern river valleys and settlers' regions of origin that McMillan (1983) and others uncovered over thirty years ago.

\section{Bam has been a migration source: LULCC is minimal}

Before the 1980s, the saturation of land coupled with frequent droughts and fewer off-farm income opportunities pushed many people to migrate out of Bam. Bam was a migration source with little LULCC from 1975 to 2000 (Figure 3 and Figure 4). These slight land use changes were potentially stimulated by decreased land availability and productivity and high out-migration of young Mossi farmers toward Côte d'Ivoire, Ghana, and the southern regions of Burkina Faso. Although people migrated for better opportunities, bare soil persisted in the area. The SWC projects were introduced to halt land degradation, rehabilitate bare soil, and make existing fields more productive. Between the 1996 and 2006 censuses, the stable LULCC and shift from a negative to a positive net migration in Bam (and throughout the northern Central Plateau) suggest that SWC improvements have potentially stabilized land degradation and rehabilitated soils (e.g. decreased rocky land and steppe; increased agricultural land) to the point where out-migration has dramatically decreased.

SWC programs and the stronger compliance with more intensive agriculture in Bam in recent years makes it possible to practice zaï on the same plot of land recurrently. Following the SWC projects, tree density has increased on cultivated lands (Landolt 2011). Cultivated areas remained stable and farmers improved soil fertility management through mixed farming and livestock systems. Many farmers using zaï say that their investment in livestock has increased because of the growing availability of fodder. These farmers argue that they have become less poor and less vulnerable to drought. Rainfall recovery might also explain lower vulnerability to drought throughout the region. Looking at a period of 30 years of remote sensing imagery, 
researchers have argued that there has been a rainfall recovery and regreening of the vegetation across the West African Sahel (Herrmann et al. 2005; Nicholson 2005).

Local restorative initiatives such as reforestation and massive SWC projects like those of PATECORE (which worked in over 200 villages) could be behind this regreening and decreased famine. According to farmers, "famines are [now] a thing of the past" because improved agricultural techniques and investment in livestock have helped them adapt to drought (West et al. 2014). In the Central Plateau of Burkina Faso, SWC projects stimulated the "rehabilitation of 200,000 to 300,000 hectares of land and the production of an additional 80,000 tons of food per year" (IFAD 2011: 3). Improved water retention, assisted natural regeneration and tree-planting programs promoted under these projects have not only increased biomass on cultivated lands, but also stimulated crop yields and improved household income, diet and health (Bayala et al. 2014; Binam et al. 2017; Brandt et al. 2014; Haglund et al. 2011; Kaboré and Reij 2003; Reij and Thiombiano 2003; Weston et al. 2015). Our fieldwork data suggests that population pressure continues to grow in Bam and that land is becoming scarce. Although some households still remain vulnerable to food insecurity due to skyrocketing global market prices, in times of food scarcity, they engage in non-farming activities such as trade, gold mining and handicrafts. In addition, they count on remittances sent from migrant relatives to buy grain on the market or rely on food aid programs.

\section{Conclusion}

In Bam and Sissili provinces of Burkina Faso, LULCC correlates with migration trends. While land degradation stimulates intensive out-migration from a province, soil rehabilitation can help decrease it. In the 1970s, land degradation in Bam led to intensive out-migration, making Bam a migration source. In order to overcome land degradation, SWC projects were introduced. The introduction of the SWC projects and rainfall recovery have stabilized LULCC in Bam, transforming the negative net migration of the province into a slightly positive net migration. This reversal in migration trends is partly due to extensive investments to conserve soil and water, making agricultural production a little more resilient. As other areas, such as Sissili, become densely populated and less welcoming to new arrivals, incentives to leave Bam for the southern, wetter zones diminish.

In Sissili, which used to be one of the preferred destinations for migrants in the 1970s, 1980s and 1990s, intensive in-migration led to a severe loss of savanna and forest and a dramatic increase in agricultural land. Increased population, deforestation, the expansion of agricultural land, increased livestock population, reduced land availability, and the development of commercial agriculture have degraded the landscape and strained social relationships. After 1985, and especially since 1996, in-migration to Sissili has drastically decreased. Declining migration toward Sissili and brewing land tenure conflicts between migrants and autochthonous communities call for controlled LULCC and conservation programs. As intensive out-migration promoted the introduction of SWC in regions of departure, the results presented here recapitulate and echo Marchal's thirty year old warning to develop conservation measures "to take care of what is left" in destination areas as well (Marchal 1983: 810).

This controlled comparison between two provinces in Burkina Faso underscores the complexity of migration and land-use/land-use dynamics. Using a mixed-method approach that combines secondary population data and LULC maps with qualitative fieldwork, we have assembled a time series of migration and environmental trends for Bam and Sissili across several decades, illustrating aspects of the regional political ecology that can be built on in future years.

\section{References}

Adeel, Z., U. Safriel, D. Niemeijer and R.White. 2005. Ecosystems and human well-being: desertification synthesis. Washington DC: World Resources Institute.

Anyamba, A. and C. Tucker. 2005. Analysis of Sahelian vegetation dynamics using NOAA AVHRR NDVI data from 1981-2003. Journal of Arid Environments 63: 596-614. 
Batterbury, S.P.J. 1997. The political ecology of environmental management in semi-arid West Africa : case studies from the Central Plateau, Burkina Faso. Ph.D. Dissertation, Geography. Worcester, MA: Clark University.

Batterbury, S.P.J. and A. Warren. 2001. Desertification. In N. Smelser and P. Baltes (eds.). International Encyclopedia of the Social and Behavioral Science. Amsterdam: Elsevier. Pp. 3526-3529.

Bayala, J., J. Sanou, Z. Teklehaimanot, A. Kalinganire and S. Ouédraogo. 2014. Parklands for buffering climate risk and sustaining agricultural production in the Sahel of West Africa. Current Opinion in Environmental Sustainability 6: 28-34.

Biersack, A. 1999. Introduction: from the "new ecology" to the new ecologies. American Anthropologist 101: 5-18.

Binam, J., F. Place, A. Djalal and A. Kalinganire. 2017. Effects of local institutions on the adoption of agroforestry innovations: evidence of farmer managed natural regeneration and its implications for rural livelihoods in the Sahel. Agricultural and Food Economics 5(1): 2.

Blaikie, P.M. and H.C. Brookfield. 1987. Land degradation and society. New York: Methuen.

Boserup, E. 1987. Population and technology in preindustrial Europe. Population and Development Review 13(4): 691-701.

Brandt, M., C. Romankiewicz, R. Spiekermann and C. Samimi. 2014. Environmental change in time series-an interdisciplinary study in the Sahel of Mali and Senegal. Journal of Arid Environments 105: 52-63.

Chambers, R. 1994. Participatory rural appraisal (PRA): challenges, potentials and paradigm. World Development 22(10): 1437-1454.

Cleveland, D. 1991. Migration in West Africa: a savanna village perspective. Africa 61(2): 222-246.

Cordell, D., J. Gregory, and V. Piché. 1996. Hoe and wage: a social history of a circular migration system in West Africa. Boulder, CO: Westview Press.

Critchley, W. 1991. Looking after our land: Soil and Water Conservation in Dryland Africa. Oxford, UK: Oxfam.

Dabiré, B., H. Koné and S. Lougué. 2009. Récensement général de la population et de l'habitation de 2006 (RGPH-2006): analyse des résultats définitifs. Theme 8: Migrations. Ouagadougou: Institut National de la Statistique et de la Démographie.

Di Gregorio, A. and L. Jansen. 1998. Land-Cover Classification System (LCCS): classification concepts and user manual. GCP/RAF/287/ITA Africover-East Africa Project and Soil Resources, Management and Conservation Service. Rome: Food and Agriculture Organization.

Drabo, I., F. Ilboudo and B. Tallet. 2003. Les disparités dans l'organisation de l'espace national. In Drabo, I., F. Ilboudo and B. Tallet. Dynamique des populations, disponibilités en terres et adaptation des régimes foncier: le Burkina Faso, une étude de cas. Ouagadougou/Paris: CICRED/FAO. Pp. 21-49.

Duperray, A. 1984. Les Gourounsi de Haute-Volta: conquête et colonisation 1896-1933. Stuttgart: Franz Steiner Verlag.

Ellis, E. 2013. Land-use and land-cover change. In R. Pontius (ed.). Encyclopedia of the Earth. [accessed May 5 2015]. http://www.ecotope.org/people/ellis/papers/ellis_eoe_lulcc_2007.pdf.

Food and Agriculture Organization (FAO) and United Nations Environment Programme (UNEP). 1997. Negotiating a sustainable future for land. [accessed January 5 2015]. http://www.fao.org/3/abo779e.pdf.

Gray, L. 1999. Is land being degraded? A multi-scale investigation of landscape change in Southwestern Burkina Faso. Land Degradation and Development 10: 329-343.

Gray, L. 2005. What kind of intensification? Agricultural practice, soil fertility and socioeconomic differentiation in rural Burkina Faso. The Geographical Journal 171(1): 70-82.

Haglund, E., J. Ndjeunga, L. Snook and D. Pasternak. 2011. Dry land tree management for improved household livelihoods: farmer managed natural regeneration in Niger. Journal of Environmental Management 92(7): 1696-1705. 
Henry, S., P. Boyle and E. Lambin. 2003. Modelling inter-provincial migration in Burkina Faso, West Africa: the role of sociodemographic and environmental factors. Applied Geography 23: 115-136.

Herrmann, S., A. Anyamba and C. Tucker. 2005. Recent trends in vegetation dynamics in the African Sahel and their relationship to climate. Global Environmental Change 15: 394-404.

Institut Géographique du Burkina. 2005. Guide technique de la nomenclature BDOT. Institut Géographique du Burkina.

International Fund for Agricultural Development (IFAD). 2011. Regreening the Sahel: developing agriculture in the context of climate change in Burkina Faso. Information sheet: West and Central Africa. IFAD.

Institut National de la Statistique et de la Démographie (INSD). 1985. Récensement général de la population: résultats définitifs, 1985. Ouagadougou, Burkina Faso: INSD.

Institut National de la Statistique et de la Démographie (INSD). 1978a. Récensement général de la population: résultats définitifs, 1975. Volume II: Les données Départementales - Département du Centre-Ouest. Ouagadougou, Burkina Faso: INSD.

Institut National de la Statistique et de la Démographie (INSD). 1978b. Récensement général de la population: résultats définitifs, 1975. Volume II: Les données Départementales - Département du Centre-Nord. Ouagadougou, Burkina Faso: INSD.

Jaques, E., B. Zida, M. Billa, C. Greffié and J. Thomassin. 2006. Artisanal and small-scale gold mines in Burkina Faso: today and tomorrow. In Hilson, G. (ed.). Small-scale mining, rural subsidence and poverty in West Africa. London: Practical Action. Pp. 114-134.

Jiang, H. 2003. Stories remote sensing images can tell: integrating remote sensing analysis with ethnographic research in the study of cultural landscapes. Human Ecology 31(2): 215-232.

Kaboré, D. and C. Reij. 2003. The emergence and spread of an improved traditional soil and water conservation practice in Burkina Faso. Paper Presented at the InWEnt, IFPRI, NEPAD, CTA Conference on "Successes in African Agriculture", Pretoria, 1-2 December 2003.

Lambin, E., B.L.Turner, H. Geist, S. Agbola, A. Angelsen, J. Bruce, O. Coomes, R. Dirzo, G. Fischer, C. Folke, P. George, K. Homewood, J. Imbernon, R. Leemans, X. Li, E. Moran, M. Mortimore, P. Ramaskrishnan, J. Richards, H. Skanes, W. Steffen, G. Stone, U. Svedin, T. Veldkamp, C. Vogel and J. Xu. 2001. The causes of land-use and land-cover change: moving beyond the myths. Global Environmental Change 11: 261-269.

Landolt, M. 2011. Stone lines against desertification. Rural 21: 36-37.

Lopez-Escartin, N. 1992. Données de base sur la population: Burkina Faso. Paris : Centre Français sur la Population et le Developpement (CEPED). [accessed May 05 2015]. http://www.ceped.org/cdrom/integral_publication_1988_2002/donnees_base/pdf/pop_burkina.pdf .

Marchal, J. 1983. La dynamique d'un espace rural Soudano-Sahelien. Paris: ORSTOM.

McMillan, D. 1983. A resettlement project in Upper Volta. PhD dissertation, Anthropology, Northwestern University.

McMillan, D. 1995. Sahel visions: planned settlement and river blindness control in Burkina Faso. Tucson, AZ: University of Arizona Press.

McMillan, D., J. Nana and K. Savadogo. 1993. Settlement and development in the River Blindness Control Zone: case study of Burkina Faso. World Bank Technical Paper 200. Washington DC: The World Bank.

Meillassoux, C. 1975. Maidens, meal and money: capitalism and the domestic community. Melbourne: Cambridge University Press.

Nicholson, S. 2005. On the question of the "recovery" of the rains in the West African Sahel. Journal of Arid Environments 63: 615-641.

Organization for Economic Co-operation and Development (OECD). 2005. Glossary statistical terms: net migration. Eurostat glossary on demographic statistics. [accessed January 052015 ]. https://stats.oecd.org/glossary/detail.asp?ID=6639 . 
Ouédraogo, I. 2010. Land-use dynamics and demographic change in Southern Burkina Faso. Ph.D. dissertation, Forest Sciences. Alnarp: Swedish University of Agricultural Sciences.

Ouédraogo, I., M. Tigabu, P. Savadogo, H. Compaoré, P. Odén and J. Ouadba. 2010. Land-cover change and its relation with population dynamics in Burkina Faso, West Africa. Land Degradation and Development 21(5): 453-462.

Paré, S., U. Söderberg, M. Sandewall and J. Ouadba. 2008. Land use analysis from spatial and field data capture in southern Burkina Faso, West Africa. Agriculture, Ecosystems and Environment 127(3-4): 277-285.

Reij, C., G. Tappan and A. Belemviré. 2005. Changing land management practices and vegetation on the Central Plateau of Burkina Faso (1968-2002). Journal of Arid Environments (63): 642-659.

Reij, C. and T. Thiombiano. 2003. Développement rural et environnement au Burkina Faso: la réhabilitation de la capacité productive des terroirs sur la partie nord du Plateau Central entre 1980 et 2001: rapport de synthèse. Ouagadougou: Ambassade des Pays-Bas.

Songré, A., J. Sawadogo and G. Sanogoh. 1974. Réalités et effets de l'émigration massive des voltaiques dans le contexte de l'Afrique occidentale. in S. Amin (ed.). Modern migrations in West Africa. Oxford, UK: Oxford University Press. Pp. 384-406.

Stamm, V., J. Sawadogo, S. Ouédraogo and D. Ouédraogo. 2003. Micro-policies on land tenure in three villages in Bam Province, Burkina Faso. London, UK: International Institute for Environment and Development.

Tappan, G., W. Cushing, S. Cotillon, M. Mathis, J. Hutchinson and K. Dalsted. 2016. West Africa Land Use Land Cover time series: U.S. Geological Survey data release. [accessed April 12 2018]. http://dx.doi.org/10.5066/F73N21JF.

Tarver, J. 1992. Lifetime migration to the major cities of the United States, Asia, and Africa. Genus 48: 63-71.

Tauxier, L.1924. Nouvelles notes sur le Mossi et le Gourounsi Paris: Larose.

Turner, B.L., R. Moss and D. Skole. 1993. Relating Land-Use and Global Land-Cover Change: a proposal for an IGBP-HDP Core Project. IGBP Report 24, HDP Report 5. Stockholm: International GeosphereBiosphere Program.

United Nations Convention to Combat Desertification (UNCCD). 1994. Elaboration of an International Convention to Combat Desertification in countries experiencing serious drought and/or desertification, particularly in Africa. U.N. Doc. A/AC.241/27, 33 I.L.M. 1328. Geneva: United Nations.

Vagen, T. and T. Gumbricht. 2012. Sahel atlas of changing landscapes: tracing trends and variations in vegetation cover and soil condition. Nairobi: United Nations Environment Programme (UNEP).

West, C.T. 2010. Household extension and fragmentation: investigating the socio-environmental dynamics of Mossi domestic transitions. Human Ecology 38: 363-376.

West, C.T. 2013. Documenting livelihood trajectories in the context of development interventions in northern Burkina Faso. Journal of Political Ecology 20: 342-360.

West, C.T., A. Somé and E. Nébié. 2014. Famines are a thing of the past: food insecurity trends in northern Burkina Faso. Human Organization 73(4): 340-350.

West, C.T., C. Roncoli and F. Ouattara. 2008. Local perceptions and regional climate trends on the Central Plateau of Burkina Faso. Land Degradation and Development 19(3): 289-304.

West, C.T. and M. Vásquez-León. 2008. Misreading the Arizona landscape: reframing analyses of environmental degradation in Southeastern Arizona. Human Organization 67(4): 373-383.

Weston, P., R. Hong, C. Kaboré and C. Kull. 2015. Farmer-managed natural regeneration enhances rural livelihoods in dryland West Africa. Environmental Management 55(6): 1402-1417.

World Health Organization. 2015. Onchocerciasis: key facts. Electronic Document. [accessed April 052015 ]. http://www.who.int/mediacentre/factsheets/fs374/en/. 